\title{
A new species of Mesochra (Copepoda: Harpacticoida: Canthocamptidae) from a coastal system of northern Colombia with a key to the American species
}

\author{
Eduardo Suárez-Morales $^{\mathrm{a} *}$ and Juan M. Fuentes-Reinés ${ }^{\mathrm{b}}$ \\ ${ }^{a}$ El Colegio de la Frontera Sur (ECOSUR), Quintana Roo, Mexico; ${ }^{b}$ Grupo de investigación en \\ Biodiversidad y Ecología Aplicada, Universidad del Magdalena, Magdalena, Colombia
}

(Received 27 August 2014; accepted 15 August 2015; first published online 18 September 2015)

\begin{abstract}
Plankton samples obtained from the Laguna Navio Quebrado, La Guajira, northern Colombia, yielded the first record of the genus Mesochra Boeck, 1865 for Colombia. It is represented by an undescribed species, $M$. huysi sp. nov., which appears to be closely related to M. parva Thomson, 1946 and M. pseudoparva Gómez \& Fiers, 1997. However, the new species can be distinguished from these two species by the insertion point of the inner seta of P1 ENP1, the length/width ratio of P1ENP, the inner seta of P1ENP2, the relative length of P3 and P4 ENP, by details of elements of P5 EXP female, the structure of the anal operculum, the remarkable ornamentation of the male P3 EXP1-2, the apophysis of the male P3 ENP2, and the claw-like or flameshaped element of male P3 ENP3. This is the third record of a species of the genus from the Caribbean. A key to the 11 species of Mesochra known from the Americas is provided.
\end{abstract}

http://zoobank.org/urn:lsid:zoobank.org:pub:02DD40CD-ECBA-4A5D-AE8014D185376272

Keywords: Taxonomy; benthic copepods; Harpacticoida; Laguna Navío Quebrado

\section{Introduction}

The Family Canthocamptidae was established by Sars (1906) by upgrading the subfamily Canthocamptinae Brady, 1880. It is the largest family in the Harpacticoida, currently comprising about 627 species, of which only $17 \%$ are known from the Neotropical region (Boxshall and Defaye 2008). Most canthocamptids inhabit fresh water (Wilson 1971) but some genera can dwell in coastal marine habitats or in brackish water, e.g. Cletocamptus and Mesochra Boeck, 1865 (Boxshall and Defaye 2008); the latter genus has been reported also from coral reef environments (Sarmento and Parrera Santos 2012). Among the 52 valid canthocamptid genera, Mesochra is one of the largest, currently comprising more than 45 valid species (Boxshall and Halsey 2004; Gaviria-Melo et al. 2013).

In Colombia, studies on the Harpacticoida have been historically sparse but have increased recently (Gaviria and Defaye 2012; Fuentes-Reinés and Zoppi 2013a, 2013b; Fuentes-Reinés and Gómez 2014; Fuentes-Reinés and Suárez-Morales 2014). In particular, the knowledge about the family Canthocamptidae is still limited in Colombia, and to date only three of the nine genera known from the Neotropical

*Corresponding author. Email: esuarez@ecosur.mx 
region (Boxshall and Defaye 2008) have been recorded from this country. Colombian canthocamptids are represented by six species of Elaphoidella (E. bidens bidens (Schmeil, 1894), E. colombiana Gaviria, 1993, E. grandidieri (Guerne \& Richard, 1893), E. radkei Reid, 1987, E. sewelli minuta (Chappuis, 1932) and E. suarezi Reid, 1987), one of Epactophanes (E. richardi Mrázek, 1893), and four of Attheyella (A. (Chappuisiella) fuhrmanni (Thiébaud, 1912), A. (C.) pichilafquensis Löffler, 1961, $A$. (Delachauxiella) freyi Löffler, 1963 and A. (Canthosella) chocoensis Gaviria and Defaye 2012). There are no previous reports of species of Mesochra from Colombian waters. Recent biological sampling at one of the largest protected coastal systems of northern Colombia yielded several male and female specimens of an undescribed species of Mesochra which is described in full in the present contribution. A key for the identification of the American species of the genus is also presented.

\title{
Material and methods
}

Biological samples of benthos and plankton were taken from the Laguna Navío Quebrado, Colombia $\left(11^{\circ} 25^{\prime} \mathrm{N}, 7^{\circ} 05^{\prime} \mathrm{W}\right)$ from April to December 2012, mainly in the littoral areas with vegetation (macrophytes and mangrove) but also from open water in areas adjacent to shallow oyster banks. Water salinity was measured with a WTW 3111 conductivity meter. Water samples were collected using a 251 bucket at both vegetation areas and open water. Samples were filtered with a standard zooplankton net (45 $\mu \mathrm{m}$ mesh) and fixed and preserved in 70\% ethanol. Copepods were sorted from the original samples. Dissected specimens and appendages were mounted in glycerine and sealed with Canada balsam or Entellan ${ }^{\circledR}$. Drawings of the mounted appendages were prepared at $1000 \times$ magnification with the aid of a camera lucida adapted to a compound microscope. The specimens were measured in lateral position, from the anterior end of the cephalic area to the posterior margin of the caudal rami. Morphological nomenclature follows Huys and Boxshall (1991) and Huys et al. (1996). The following abbreviations are used in the text and tables: P1-P6, first to sixth swimming legs; EXP, exopod; ENP, endopod. The type specimens examined were deposited in the collection held at the Museo de Colecciones Biológicas de la Universidad del Atlántico (UARC), Barranquilla, Colombia and in the Collection of Zooplankton at El Colegio de la Frontera Sur in Chetumal, Mexico (ECO-CHZ).

\section{Systematics}

\author{
Order HARPACTICOIDA Sars, 1903 \\ Family Canthocamptidae Brady, 1880 \\ Genus Mesochra Boeck, 1865 \\ Mesochra huysi sp. nov.
}

(Figures 1-4)

\section{Material examined}

Female holotype (UARC390), male allotype (UARC391), from shallow plankton samples, Laguna Navío Quebrado, Colombia $\left(11^{\circ} 25^{\prime} \mathrm{N}, 73^{\circ} 05^{\prime} \mathrm{W}\right)$, partially dissected, 


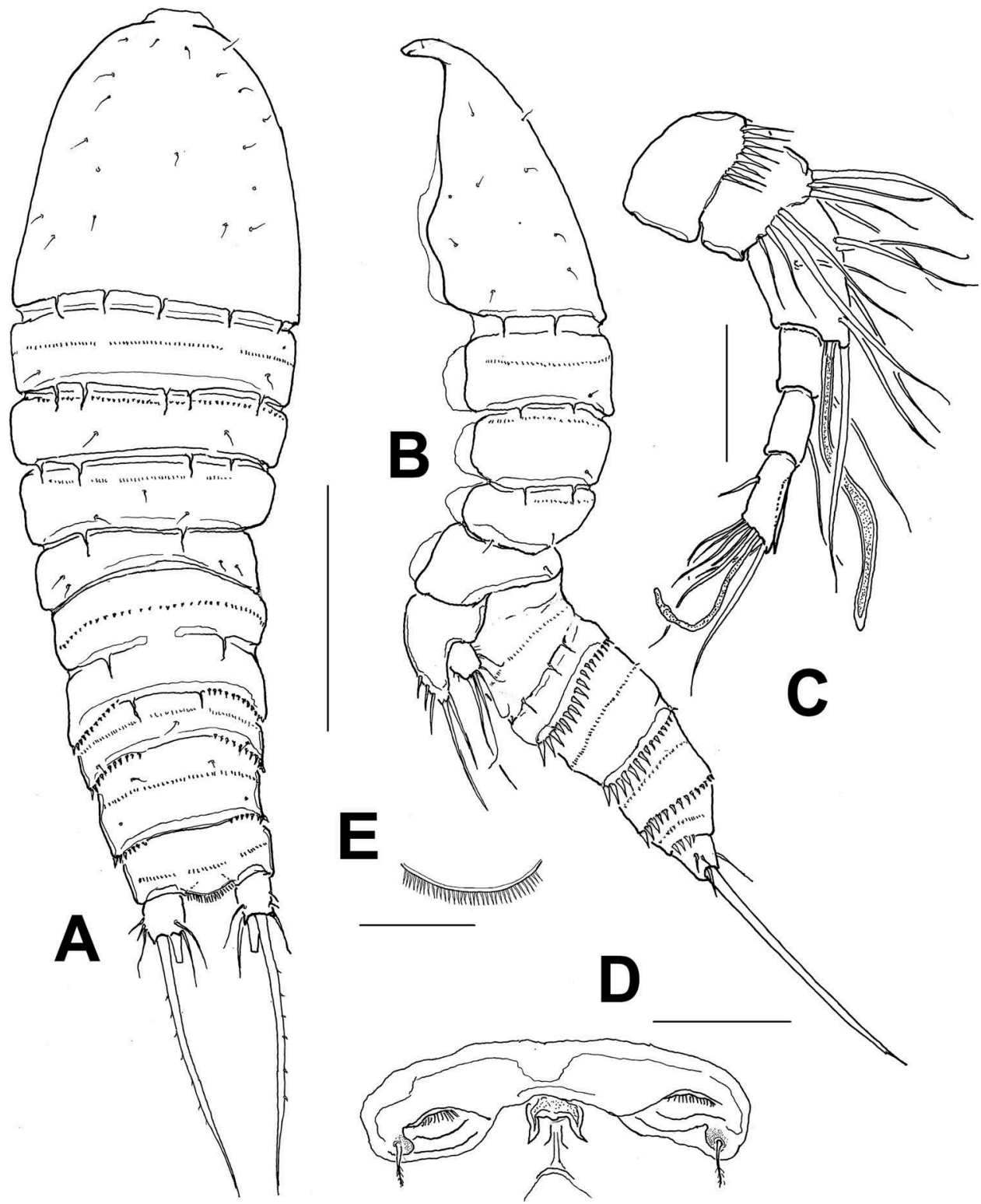

Figure 1. Mesochra huysi sp. nov., adult female from Colombia: (A) habitus, dorsal view; (B) same, lateral view; (C) antennule; (D) genital field and sixth legs, ventral view; (E) anal operculum, dorsal view. Scale bars: A, B $=100 \mu \mathrm{m}, \mathrm{C}-\mathrm{E}=20 \mu \mathrm{m}$.

semi-permanent slides. Paratypes: one female, one male, plus two undissected females and two males, ethanol-preserved, vial (UARC392). Three adult females and two adult males, dissected, mounted in slides, same locality, and collector (ECOCHZ09325). Additional material: 5 adult females, 5 adult males in author's (JF-R) personal collection; these specimens are available for consultation upon request. 

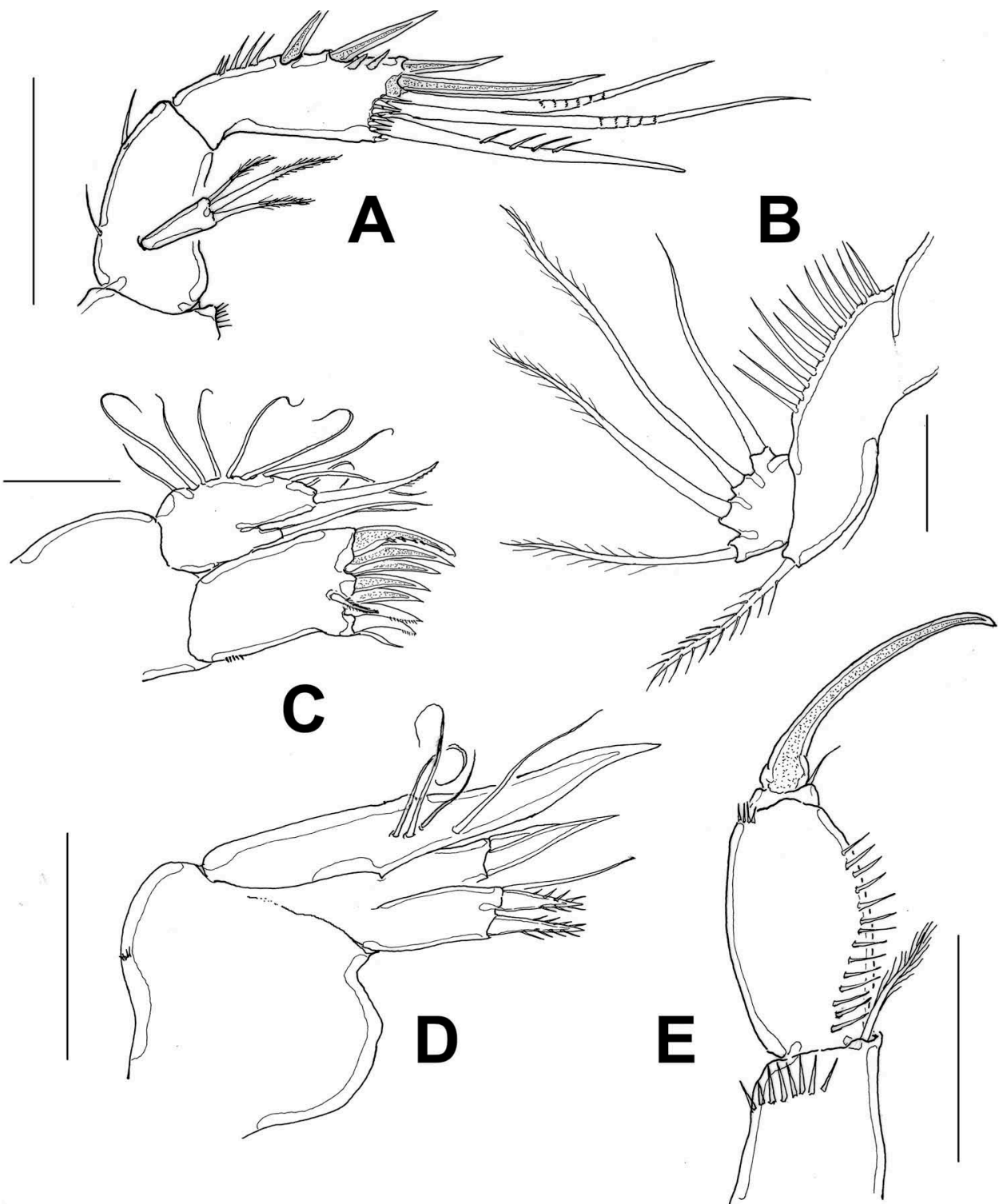

Figure 2. Mesochra huysi sp. nov., adult female from Colombia: (A) antenna; (B) mandibular palp; (C) maxillule; (D) maxilla; (E) maxilliped. Scale bars: A, D, E = $20 \mu \mathrm{m}, \mathrm{B}, \mathrm{C}=10 \mu \mathrm{m}$.

\section{Type locality}

Laguna Navío Quebrado, La Guajira, Colombia $\left(11^{\circ} 25^{\prime} \mathrm{N}, 73^{\circ} 05^{\prime} \mathrm{W}\right)$.

\section{Description of female}

Body fusiform, slightly tapering posteriorly (Figure 1A). Habitus in dorsal view as in Figure 1A, in lateral view as in Figure 1B. Total body length, measured from tip of rostrum 


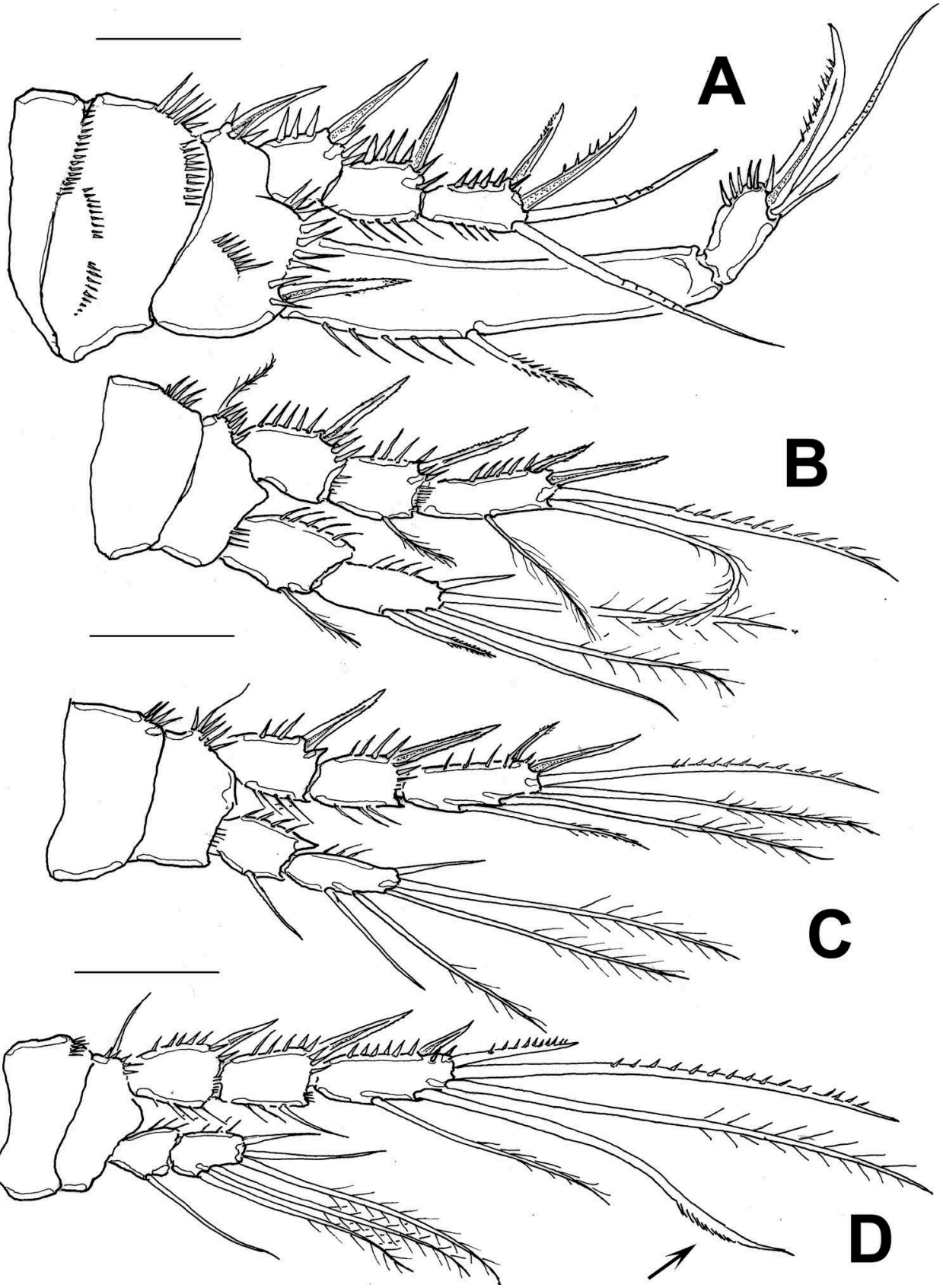

Figure 3. Mesochra huysi sp. nov., adult female from Colombia: (A) leg 1; (B) leg 2; (C) leg 3; (D) leg 4. Scale bars: $20 \mu \mathrm{m}$. 


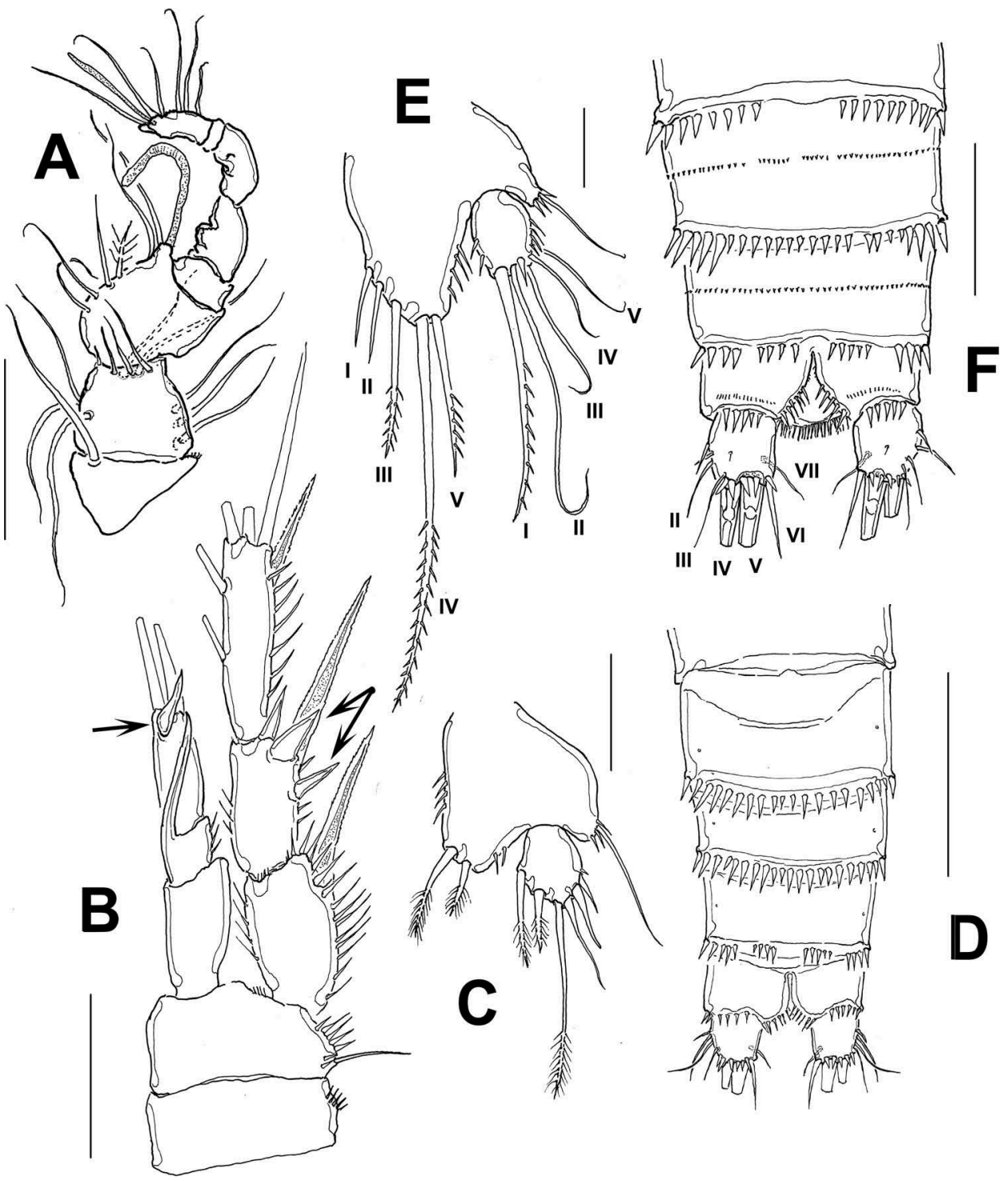

Figure 4. Mesochra huysi sp. nov., adult male from Colombia: (A) antennule; (B) leg 3 showing flame-shaped element (arrowed) and remarkably large spinules on second exopodal segment (double arrow); (C) P5; (D) ornamentation of urosome and caudal rami, ventral view. Adult female, (E) P5 showing setal nomenclature (Huys et al. 1996); F. ornamentation of urosome and armature of caudal rami, ventral view. Scale bars: A-C, $E=20 \mu \mathrm{m}, \mathrm{D}, \mathrm{F}=50 \mu \mathrm{m}$.

to posterior margin of caudal rami ranging from 336 to $403 \mu \mathrm{m}$ (average $374 \mu \mathrm{m}, n=10$; holotype: $336 \mu \mathrm{m}$ ). Rostrum distinct, flat in dorsal view, subtriangular, with rounded tip in lateral view. Dorsal surface of cephalosome and free prosomites with incised hyaline frill. Transverse row of microspinules on dorsal surface of first three pedigerous free somites, fourth free somite without dorsal spinulation. Genital double-somite with vestigial suture 
visible in ventral view, first genital somite with row of small spinules on mid-dorsal surface and posterior frill; second genital somite with transverse row of spinules and weak frill along posterior margin on dorsal surface (Figure 1A); lateral and ventral margins with larger set of spinules (Figures 1B, 4D). First and second free urosomites with mid-dorsal row of minute spinules and row of spinules along posterior margin, spinules increasing in size laterally and ventrally (Figure 4D). Anal somite with separate transverse rows of minute spinules on mid-dorsal surface, distal margin with short row of spinules along insertion of caudal rami. Anal operculum rounded, ornamented with slender spinules (Figure 4F).

Caudal rami (Figure 4F) subquadrate, with six setae, with spinules along ventral surface. Seta II with accompanying spinules, and about as long as caudal rami, seta III 1.2 times as long as seta II, seta V about 4.2 times longer than seta IV and seta VII as long as seta II.

Antennule. 6-segmented, with distal row of 8-9 spinules on first segment. Aesthetasc on third segment reaching well beyond last segment, this segment with small outer spine (Figure 1C). Armature formula as follows: 1(0), 2(8), 3(7+1ae), 4(1), 5(1), 6(9+ae).

Antenna. Allobasis with two short setae, one proximal and one on subdistal position. Exopod short, cylindrical, 1-segmented, with three unequally long terminal setae, middle setae being longest. Endopod 1-segmented, inner margin with row of spinules on proximal $1 / 3$ of segment, lateral armature represented by two subequal spines plus two outer spinules distally. Distal margin with five setal elements, two spines, two geniculate setae and one stout seta furnished with spinules (Figure 2A).

Mandible. Gnathobase with strong, wide teeth and one plumose dorsal seta, basis elongate, armed with one basipodal seta and row of long spinules. Endopodal lobe armed with four setae (Figure 2B).

Maxillule. Praecoxal arthrite with two setae. Distal margin with five strong curved claws and four setal elements. Coxa and basis partially fused; coxal endite with two slender setae. Basis with one seta. Endopodal and exopodal rami fused to basis, each represented by four and four setae, respectively (Figure 2C).

Maxilla. Syncoxa ornamented with row of minute spinules, with two endites, each with three setal elements, two of them wide-based, spinulated, the other slender. Basis forming strong claw with one slender seta. Endopod represented by three slender setae (Figure 2D).

Maxilliped. Syncoxa furnished with subdistal row of spinules, with inner distal plumose seta reaching half-length of basis. Basal segment robust, ornamented with longitudinal row of long spinules from proximal margin to distal $1 / 3$ of segment; distal outer margin with row of small spinules. Endopod represented by weakly curved claw with an accompanying proximal seta (Figure 2E).

P1 (Figure 3A). Protopod ornamented with row of spinules along posterior margin, coxa with proximal rows of minute spinules, additional rows also along outer and posterior margins. Basis with curved row of spinules on middle surface; segment with strong spinules along distal margin, particularly near insertion of endopod; with outer and inner spine, latter stout, straight, reaching about $1 / 3$ of ENP1. ENP 2-segmented, longer than EXP, first segment reaching well beyond length of EXP, about 7 times as long as wide, inner seta on first segment inserted almost at the half of segment; second segment ornamented with outer row of spinules, armed with three elements, inner subdistal one shorter than segment. EXP 3-segmented, reaching beyond insertion of inner seta on ENP1, EXP1 and EXP2 without inner setae, third segment with four elements, two of them geniculate. 
Table 1. Armature formula of legs 1-4.

\begin{tabular}{lllll}
\hline & \multicolumn{1}{c}{ P1 } & \multicolumn{1}{c}{ P2 } & \multicolumn{1}{c}{ P3 } & \multicolumn{1}{c}{ P4 } \\
\hline Basis & I, I & 1,0 & 1,0 & 1,0 \\
Exopod & I-0;I-0;II,2,0 & I-0;I-1,II,2,1 & I-0;I-0;II,2,2 & I-0;I-0;II,2,2 \\
Endopod & $0-1 ; 0, \mathrm{I}, 2,0$ & $0-1 ; 1,2,2$ & $0-1 ; \mathrm{I}, 2,2$ & $0-1 ; \mathrm{I}, 2,2$ \\
\hline
\end{tabular}

P2 (Figure 3B). Coxa and basis with weaker ornamentation than in P1. Basis with slender outer basipodal seta. ENP 2-segmented, shorter than EXP, not reaching midlength of EXP3. ENP1 with outer seta, without inner seta, ENP2 with five setal elements. EXP 3segmented, EXP1 without inner seta, EXP2 with short inner seta, EXP3 with five elements.

P3 (Figure 3C). Coxa and basis with weaker ornamentation than in P1, as in P2. Basis with slender outer basipodal seta. ENP 2-segmented, barely reaching distal end of EXP2; ENP1 with outer seta, without inner seta; ENP2 with five elements. EXP 3-segmented, EXP1 and EXP2 without inner setae, third segment with six elements.

P4 (Figure 3D). Coxa and basis with weaker ornamentation than in P1, as in P2 and P3. Basis with slender outer basipodal seta. ENP 2-segmented, short, reaching only proximal 1/3 of EXP1; ENP1 with inner seta, without outer seta; ENP2 with five setal elements. EXP 3-segmented, EXP1 with inner seta, third segment with six elements, one of them a thickened pectinate seta (arrowed in Figure 3D).

P5 (Figure 4C). Baseoendopod with single seta. EXP rounded, shorter than endopodal lobe, with five elements, inner middle distal seta longer than inner distal spine. Endopodal lobe armed with five elements (Figure 4E). Setal formula (Arabic numerals $=$ setae, Roman numerals $=$ spines) of P1-P4 as in Table 1.

P6 (Figure 1D) vestigial, represented by small crescent-shaped lobe (Figure 1D), with one short seta.

\section{Description of male}

Habitus resembling that of female except for narrower prosome and urosome (Figure 4D). Smaller than female, total body length, measured from tip of rostrum to posterior margin of caudal rami ranging from 263 to $315 \mu \mathrm{m}$ (average $289 \mu \mathrm{m}, n=5$; holotype: $263 \mu \mathrm{m}$ ). Somitic ornamentation as in female. Urosomites 1-3 with ventral row of large spinule along posterior margin (Figure 4D) which are coarser than those along the dorsal surface. Row of spinules along ventral margin of preanal somite with discontinuous row of spinules, as opposed to female, with continuous such row. Anal somite as in female, with smaller spinules on ventral surface and along insertion of caudal rami. Armature of caudal rami as in female.

Antennule. Geniculate, 8-segmented (Figure 4A).

Mouthparts, P1, P2, and P4 as in female.

P3 (Figure 4B). Coxa and basis with weaker ornamentation than in female P1, as in female P2. Basis with slender outer basipodal seta. ENP 3-segmented, shorter than EXP, reaching proximal 1/4 of EXP3; ENP1 unarmed, ENP2 without inner seta but with inner sinuous apophysis reaching apical margin of ENP3; ENP3 with two distal setae and a single claw-like or flame-shaped (Gómez and Fiers 1997) element (arrowed in Figure 4B). EXP 3-segmented, EXP1 and EXP2 with strong, long 
outer spine. EXP2 ornamented with noticeably strong, wide-based spinules (double arrow in Figure 4B). EXP3 with 6 setal elements, two of them on inner margin (Figure 4B).

P5 (Figure 4C). Baseoendopod with cluster of spinules at point of insertion of seta. EXP rounded, reaching slightly beyond distal margin of endopodal lobe, with six setal elements, middle seta being longest. Endopodal lobe ornamented with few small spinules along inner and outer margins, armed with two spines of unequal length.

\section{Etymology}

The new species is named after Dr Rony Huys (Natural History Museum, London, UK), for his outstanding contributions to the taxonomic knowledge of the Harpacticoida.

\section{Remarks}

Mesochra huysi sp. nov. most closely resembles $M$. parva Thomson, 1946, M. pacifica Gómez and Fiers, 1997, and M. pseudoparva Gómez and Fiers, 1997; they share an identical armature formula of P1-P4. The female fifth leg armature, with five setal elements on the fifth leg EXP also resembles that of M. parva (Hamond 1971, fig. 13), M. pacifica (Gómez and Fiers, 1997, fig. 5b) and M. pseudoparva (Gómez and Fiers 1997, fig. 11b). However, $M$. huysi sp. nov. can be separated from these species when comparing the insertion of the inner seta P1 ENP1. It is at the same level of the distal margin of P1 EXP3 in both M. parva (Hamond 1971, fig. 14) and M. pseudoparva (Gómez and Fiers 1997, fig. 10a), it is inserted beyond the distal end of P1EXP3, in the distal 1/3 of the ENP1 in $M$. pacifica (Gómez and Fiers 1997, fig. 4a), while in M. huysi this seta is at the level of half the length of P1EXP3 (Figure 3A). Also, the length/width ratio of the P1ENP1 is different in these species: is similar in both M. parva (from Hamond 1971, fig. 14) and M. pseudoparva (from Gómez and Fiers 1997, fig. 10a), 6.0 in M. pacifica (from Gómez and Fiers 1997, fig. $4 \mathrm{a})$ and 5.0 in the new species, M. huysi. The length ratio of the inner seta of P1ENP2/ length of P1ENP2 reveals some additional differences among these species. The seta is short, only about half as long as the second endopodal segment in both M. parva (Hamond 1971, fig. 14) and M. huysi (Figure 3A) but it is as long as the second endopodal segment in M. pacifica (Gómez and Fiers 1997, fig. 4a) and it is longest, 1.3 longer than the P1ENP2, in M. pseudoparva (Gómez and Fiers 1997, fig. 10a). In addition, the distal end of P3 ENP reaches the proximal 1/3 of P3 EXP3 in $M$. parva (Hamond 1971, fig. 16) while in $M$. pseudoparva (Gómez and Fiers 1997, fig. 10d), M. huysi (Figure 3C), and M. pacifica (Gómez and Fiers 1997, fig. 4c), the ENP reaches the distal margin of P3EXP2. The P4 ENP reaches the distal margin of P4 EXP2 in M. parva (Hamond 1971, fig. 17), half of EXP2, almost reaching the insertion of the inner seta of EXP2 in M. pseudoparva (Gómez and Fiers 1997, fig. 11a), and the proximal 1/3 of P4 EXP2 in both M. huysi (Figure 3D) and M. pacifica (Gómez and Fiers 1997, fig. 5a). The anal operculum is naked in M. parva (Hamond 1971, fig. 6) and M. pseudoparva (Gómez and Fiers 1997, fig. 8a) whereas it is furnished with fine spinules in both $M$. huysi (Figures 1A, 4F) and also in M. pacifica (Gómez and Fiers 1997, fig. 6a, b).

The male of $M$. huysi sp. nov. differs from the male of its congeners $M$. pseudoparva, $M$. pacifica and $M$. parva by the features of the outer spinules on the first and second segments of P3 EXP; such spinules are remarkably strong in $M$. huysi while in the other three species, M. parva (Hamond 1971, fig. 20), M. pacifica (Gómez and Fiers 
1997, fig. 7b) and M. pseudoparva (Gómez and Fiers 1997, fig. 13a) these elements are slender, regular spinules. The apophysis of P3 ENP2 differs among these species. This structure does not reach the distal end of P3ENP3 in M. pseudoparva (Gómez and Fiers 1997, fig. 13a), M. pacifica (Gómez and Fiers 1997, fig. 7b) and M. huysi (Figure 4B) but in $M$. parva it is clearly shorter, not reaching the midlength of P3ENP3 (Hamond 1971, fig. 20). The claw-like or flame-shaped elements in P3 ENP3 are unreported or absent in both M. parva (Hamond 1971, fig. 20) and M. pacifica (Gómez and Fiers 1997, fig. 7b), but one is present in $M$. huysi (arrowed in Figure 4B) and two in $M$. pseudoparva (Gómez and Fiers 1997, fig. 13a, b). As mentioned by Gómez and Fiers (1997), these structures are likely to be overlooked by its size and position in some cases or even confused with other setal elements; their homologies or function cannot be established yet. The male P5 EXP has six setal elements in M. huysi, M. pseudoparva (Gómez and Fiers 1997, fig. 13c) and M. pacifica (Gómez and Fiers 1997, fig. 7c), while only five are present in M. parva (Hamond 1971, fig. 21).

Following Wells' (2007) key, our specimens are grouped among several species of Mesochra (key KG 33) (M. sewelli Lang, 1948, M. meridionalis Sars, 1905, M. pseudoparva, M. parva, M. wolskii Jakubisiak, 1933, M. lindbergi Petkovski, 1964, M. rostrata Gurney, 1927 and M. aestuarii Gurney, 1921) by its possession of a combination of characters including the segmentation of P1 rami, the number of segments on P2ENP and P4ENP, and the number of setae on the EXP3 of P2-P4. The new species is then compared (KG 33/2) with M. pacifica and M. suifunensis Borutsky, 1952, both sharing the same ornamentation of the anal operculum, armature of ENP2 of P2-P4 and armature of male and female fifth legs. Mesochra suifunensis clearly differs from the new species, $M$. huysi, in the lack of inner seta on ENP1 of P2 and P3; these setae are present in the new species. Also, the male of $M$. suifunensis lacks an apophysis in the $\mathrm{P} 3$, which is present in $M$. huysi. Therefore, the unique combination of characters of these specimens from Colombia appears to be enough evidence to consider them as belonging to a new species of Mesochra.

\section{Distribution and ecology}

Hamond (1971) recognized 31 valid species of Mesochra and presented a key based on Lang's (1948) work. Fiers and Rutledge (1990) recognized, apart from Mielke's (1974) Mesochra sp., 34 valid species. Gómez and Fiers (1997) added M. pacifica and $M$. pseudoparva. The number of species increased with the addition of three species from Iceland (Gómez and Steinarsdóttir 2007), and one from South Korea (Lee and Chang 2008). Gaviria-Melo et al. (2013) recognized up to 45 species of Mesochra; hence, with the addition of this new species from Colombia, the number of species in the genus rises to 46 . Overall, from the valid species of Mesochra, only about $25 \%$ of them have been recorded in the Americas, Brazil harbouring the highest number of species of this genus (Reid 1998).

According to Fiers and Rutledge's (1990) and to our comparative analysis, only 11 species (M. lindbergi Petkovski, 1964, M. dulcicula Jakobi, 1956, M. suifunensis Borutsky, 1952, M. meridionalis Sars, 1905, M. aestuari Gurney, 1921, M. wolskii Jakubisiak, 1933, M. rostrata Gurney, 1927, M. sewelli Lang, 1948, M. parva Thomson, 1946, M. pacifica Gómez \& Fiers, 1997, and M. pseudoparva Gómez \& Fiers, 1997 have a 2-segmented P1 ENP combined with a 222 spine formula (number of spines on the ultimate exopodal segment of P2-P4). The new species M. huysi can be assigned to this group. Only four species of this group (M. dulcicula, M. pacifica, $M$. pseudoparva and the new species, M. huysi) are known to be distributed in the 
Americas. There are only 10 species of the genus known from the continent (Gómez and Fiers 1997; Suárez-Morales et al. 2006; Sarmento and Parrera Santos 2012; Gómez and Morales-Serna 2014), a figure that reaches 11 with the addition of the new species. Only two of these species of Mesochra have been known from the Caribbean, the nominal M. pygmaea (Claus, 1863) from Barbados (Coull 1970), which is probably a species complex (Wells 2007), and a Mesochra sp. from the Mexican Caribbean coast (Suárez-Morales et al. 2006). This is the third record of a species of this genus from the Caribbean.

Mesochra huysi is currently known from a single locality, Laguna Navío Quebrado (Colombia). It was found in the limnetic region associated to a salinity of 28 psu. This large (surface area $=10.7 \mathrm{~km}^{2}$ ) and shallow (depth range $=30$ $110 \mathrm{~cm}$ ) lagoonal system has a temperature ranging between 28 and $31^{\circ} \mathrm{C}$, and $\mathrm{pH}$ values were 7.8-8.3. This is the same kind of lagoonal environment from which its closest congeners, C. pacifica, C. parva and C. pseudoparva (Hamond 1971; Gómez and Fiers 1997) have been collected. Currently, up to 14 species of Harpacticoida have been recorded in this water body (Fuentes-Reinés and Suárez-Morales 2014).

\section{Key to the American species of Mesochra (females)}

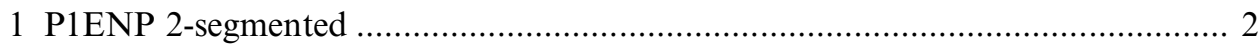

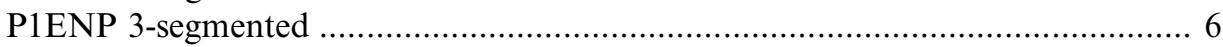

2 P2-P4EXP3 with outer spine formula 333 ................... M. lilljeborgi Boeck, 1865 P2-P4EXP3 with outer spine formula 222 ............................................. 3

3 Antennules with 6 segments, female and male P5EXP with five or six elements... 4 Antennules with 7 segments, female P5EXP with 4 elements.

M. dulcicula Jakobi, 1956

4 Anal operculum naked, female and male P5EXP with five elements, male P3ENP3 with two claw-like elements. .... M. pseudoparva Gómez \& Fiers, 1997 Anal operculum with fine cilium, female and male P5EXP with five or six elements.

5 Spine on P1ENP1 inserted beyond distal margin of P1EXP3, female and male P5EXP with five elements. Male P3ENP3 with no claw-like elements

M. pacifica Gómez \& Fiers, 1997 Spine on P1ENP1 inserted at about half-length of P1EXP3, female P5EXP with five elements, male with six. Male P3ENP3 with one claw-like element M. huysi sp. nov.

6 P1ENP1 long, going beyond P1EXP3. .......................................................... 7 P1ENP1 short, reaching the end of P1EXP2 ............. M. mexicana Wilson, 1971

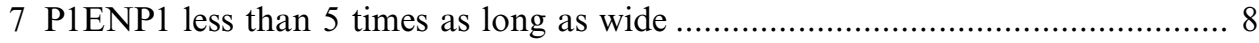
P1ENP1 more than 5 times as long as wide ............................................ 9

8 Length of inner seta of P1ENP2/length P1ENP2 ratio about 1, anal operculum with teeth or spines M. alaskana Wilson, 1958 Length of inner seta of P1ENP2/length P1ENP2 ratio about 1.5, anal operculum without teeth, P2EXP with six setae. M. rapiens (Schmeil, 1894) 
9 Inner seta of P1 ENP inserted at the level of distal margin of P1EXP2, P2EXP3 with six setal elements M. stellfeldi Jakobi, 1954 Inner seta of P1ENP1 inserted at a different level, P2EXP3 with seven setal elements 10

10 Inner seta of P1ENP1 inserted at proximal 1/3 of P1EXP3

M. paranaensis Jakobi, 1954

Inner seta of P1ENP1 inserted at distal 1/3 of P1EXP3.

M. pygmaea (Claus, 1863)*

*As mentioned by Wells (2007) this nominal species is probably a widely distributed species complex; American records should be treated and compared in detail.

\section{Acknowledgements}

We are very grateful to Dr Gómez Samuel (Instituto de Ciencias del Mar y Limnología, Unidad Académica Mazatlán, Sinaloa, Mexico) and Rony Huys (Natural History Museum, London) for kindly providing useful taxonomic literature during the development of this work. Rosa María Hernández deposited and registered the specimens in the Collection of Zooplankton of El Colegio de la Frontera Sur (ECOSUR). The comments of two anonymous reviewers greatly contributed to the improvement of an earlier version of this work.

\section{Disclosure statement}

No potential conflict of interest was reported by the authors.

\section{References}

Boeck A. 1865. Oversigt over de ved Norges Hyster iagttagne Copepoder henhörende til Calanidernes, Cyclopidernes og Harpacticidernes Familier. Forhandlinger i Videnskabsselskabet i Kristiania 1864:1-57.

Borutsky EV. 1952. Harpacticoida presnykh vod. Fauna SSSR, Rakoobraznye. 3:1-424. Russian.

Brady GS. 1880. A monograph of the free and semi-parasitic Copepoda of the British Islands. Vol. II. London: The Ray Society; 182 p. Publ. 55.

Boxshall GA, Defaye D. 2008. Global diversity of copepods (Crustacea: Copepoda) in freshwater. Hydrobiologia. 595:195-207.

Boxshall GA, Halsey SH. 2004. An introduction to copepod diversity. London: The Ray Society; 966 p. Publ. 166.

Chappuis PA. 1932. Notes Sur les copépodes. 5. Canthocamptinae d'Africa Centrale et de Madagascar. 6. Harpacticoides des Iles Kouriles. 7 Le mâle d'Elaphoidella pectinata (Delachaus). Bulletin de la Société des Sciences de Cluc (Roumanie) 6:421-428.

Coull BC. 1970. Harpacticoid copepods from Barbados and Jamaica, W.I., with descriptions of two new species. Caribb J Sci. 10:129-135.

Fiers F, Rutledge P. 1990. Harpacticoid copepods associated with Spartina alterniflora culms from the marshes of Cocodrie. Louisiana (Crustacea, Copepoda). Bull Inst Royal Sci Nat Belg. 60:105-125.

Fuentes-Reinés JM, Gómez S. 2014. A new species of Schizopera (Copepoda: Harpacticoida: Miraciidae) from Colombia. Rev MVZ Córdoba. 19:4199-4213. 
Fuentes-Reinés JM, Suárez-Morales E. 2014. Annotated checklist and new records of Harpacticoida (Copepoda) from a coastal system of northern Colombia, South America. Crustaceana. 87:212-255.

Fuentes-Reinés JM, Zoppi E. 2013a. Occurrence of Elaphoidella grandidieri (Guerne and Richard, 1893) (Crustacea: Copepoda: Harpacticoida) in Ciénaga Grande de Santa Marta, Colombia. CheckList. 9:1580-1583.

Fuentes-Reinés JM, Zoppi E. 2013b. Harpacticoid copepods from Ciénaga Grande de Santa Marta, Colombia. Mét Ecol Sist. 8:5-28.

Gaviria S. 1993. Zwei Canthocamptidae (Copepoda, Harpacticoida) aus kolombianischen Andengewässern. Annalen des Naturhistorischen Museum in Wien 94/95:361-375.

Gaviria S, Defaye D. 2012. A new species of Attheyella (Canthosella) from Colombia and redescription of Attheyella (Delachauxiella) freyi (Copepoda: Harpacticoida: Canthocamptidae). Zootaxa. 3179:1-38.

Gaviria-Melo S, Boxshall GA, Walters TC, Huys R. 2013. Mesochra Boeck 1865. World of Copepods database. [cited 2014 Mar 11]. Available from: http://www.marinespecies.org/ copepoda/aphia.php?p=taxdetails\&id $=115237$

Gómez S, Fiers F. 1997. Two new species of Mesochra Boeck, 1864 (Copepoda: Harpacticoida) from a coastal lagoon in Sinaloa State, Mexico. Bull Inst Royal Sci Nat Belg. 67:39-56.

Gómez S, Morales-Serna FN. 2014. Updated checklist of published and unpublished records of harpacticoid copepods (Crustacea: Copepoda: Harpacticoida) from Mexico. Proc Biol Soc Wash. 127:99-121.

Gómez S, Steinarsdóttir MB. 2007. On three new species of Mesochra Boeck, 1865 (Harpacticoida: Canthocamptidae) from Iceland. J Nat Hist. 41:2447-2478.

Guerne MJ de, Richard J. 1893. Canthocamptus grandidieri, Alona cambouei, nouveaux Entomostracés d'eau douce de Madagascar. Mémoires de la Société Zoologique de France 6:214-224.

Gurney R. 1921. Two new British Entomostraca: Alona protzi Hartwig, and a new species of Mesochra in Norfolk. Ann Mag Nat Hist. 7:236-243.

Gurney R. 1927. Zoological results of the Cambridge expedition to the Suez Canal, 1924. XXXIII. Report on the Crustacea: Copepoda (littoral and semi-parasitic). Trans Zool Soc London. 22: 451-577.

Hamond R. 1971. The Australian species of Mesochra (Crustacea: Harpacticoida), with a comprehensive key to the genus. Aust J Zool Suppl Ser. 19:1-32.

Huys R, Boxshall GA. 1991. Copepod evolution. London: The Ray Society; 468 p.

Huys R, Gee JM, Moore CG, Hamond R. 1996. Marine and Brackish Water Harpacticoid Copepods. Part 1: keys and notes for identification of the species. In: Barnes RSK, Crothers JH, editors. Synopses of the British Fauna (New Series) 51. Shrewsbury (UK): Field Studies Council; p. 1-352.

Jakobi H. 1954. Harpacticoida (Cop. Crust.) da microfauna do substrato areno-lodoso do 'Mar de Dentro' (Ilha do Mel - Bais de Paranaquá - Brasil). Dusenia. 5:209-232.

Jakobi H. 1956. Novas espécies de Harpacticoidea (Copepoda-Crustacea) provenientes de regioes de água salobra da costa Sao Paulo-Paraná. (Neue Harpacticoiden-Arten (Copepoda-Crustacea) aus den Brackwassergebieten der Küste Sao Paulo-Paraná). Dusenia, Curitiba. 7:159-171.

Jakubisiak S. 1933. Harpaktikoidy wód slonawych Kuby. Sur les Harpacticoïdes saumâtres de Cuba. Annales du Musée de Zoologie Polonaise. 10:93-96.

Lang K. 1948. Monographie der Harpacticiden. Vol. 2. Lund (Sweden): Håkan Ohlssons Bøktryckeri; $1682 \mathrm{p}$.

Lee JM, Chang CY. 2008. Two canthocamptid copepods of the genera Itunella and Mesochra (Harpacticoida, Canthocamptidae) from brackish waters in South Korea. J Nat Hist. 42:1729-1747. 
Löffler H. 1961. Zur Systematik und Ökologie der chilenischen Süßwasserentomostraken. Beiträge zur Neotropische Fauna 2:143-248.

Löffler H. 1963. Zur Ostrakoden- und Copepodenfauna Ekuadors. Archiv für Hydrobiologie 59: 196-234.

Mielke W. 1974. Eulitoral Harpacticoidea (Copepoda) von Spitzbergen. Mikrofauna Meeres. 37:1-52.

Mrázek A. 1893. Beitrag zur Kenntnis der Harpacticiden Fauna des Süsswassers. Zoologische Jahrbücher Abteilung fiir Systematik, Geographie und Biologie der Thiere 7:88-130.

Petkovski TK. 1964. Zur Kenntnis der Harpacticiden Portugals (Crustacea, Copepoda). Lund Universitets Årsskrift. 59:3-22.

Reid JW. 1987. Some cyclopoid and harpacticoid copepods from Colombia, including descriptions of three new species. Proc Biol Soc Wash. 100:262-271.

Reid JW. 1998. Maxillopoda - Copepoda. Harpacticoida. In: Young OS, editor. Catalogue of Crustacea of Brazil (Vol. 6). Rio de Janeiro: Museu Nacional. Série Livros; p. 75-127.

Sarmento VC, Parrera Santos PJ. 2012. Species of Harpacticoida (Crustacea, Copepoda) from the phytal of Porto de Galinhas coral reef, northeastern Brazil. CheckList. 8:939-939.

Sars GO. 1903. An account of the Crustacea of Norway. Copepoda Harpacticoida. Vol. V. Parts I and II. Bergen: Bergen Museum; p. 1-28.

Sars GO. 1905. Pacifische Plankton-Crustaceen. (Ergebnisse einer Reise nach dem Pacific. Schauinsland 1896-1897). II. Brackwasser-Crustaceen von den Chatham-Inseln. Zoologische Jahrbucher, Abteilung für Systematik. 21:371-414.

Sars GO. 1906. An account of the Crustacea of Norway. Volume V. Copepoda Harpacticoida, parts 11-16. 133-196. Pl. XLVIII-CXXVIII. Bergen: Bergen Museum.

Schmeil O. 1894. Einige neue Harpacticiden-Formen des Süsswassers. Zeitschrift für Naturwissenschaften 67:341-350.

Suárez-Morales E, De Troch M, Fiers F. 2006. A checklist of the marine Harpacticoida (Copepoda) of the Caribbean Sea. Zootaxa. 1285:1-19.

Thiébaud M. 1912. Copépodes de Colombie et des Cordillères de Mendoza En O. Fuhrmann, E. Mayor (eds.) Voyage d'Exploration Scientifique en Colombie Mémoires de la Societé Neuchâteloise de Sciences Naturelles 5:160-175.

Thomson JM. 1946. New Crustacea from the Swan River estuary. J R Soc West Aust. 30:3553.

Wells JBJ. 2007. An annotated checklist and keys to the species of Copepoda Harpacticoida (Crustacea). Zootaxa. 1568:1-872.

Wilson MS. 1958. North American harpacticoid copepods. 4. Diagnosis of new species of fresh water Canthocamptidae and Cletodidae (genus Huntemannia). Proc Biol Soc Wash. 71:43-48.

Wilson MS. 1971. North American harpacticoid copepods. 9. A new Mesochra (Canthocamptidae) from the Gulf of Mexico with notes on a related Mediterranean form. Proc Biol Soc Wash. 83:483-492. 